\title{
Communication Peculiarities of International and Ukrainian Brands in Social Networks (Facebook, Twitter, Instagram)
}

\author{
D. Oltarzhevskyi, O. Kliuchnykova, K. Sokolova, Y. Tsymbalenko*
}

Taras Shevchenko National University of Kyiv, Institute of Journalism
*Corresponding author. E-mail: e.tsymbalenko@knu.ua

Paper received 18.11.18; Accepted for publication 24.11.18.

\section{https://doi.org/10.31174/SEND-HS2018-185VI31-17}

\begin{abstract}
The main goal of the study is to find out the patterns and differences in the positioning of 10 international brands from the Forbes list and 10 leading Ukrainian brands in the most popular social networks. Through statistical and content analysis there have been identified the quantitative and qualitative indicators of their representation on Facebook, Twitter, Instagram, and also reviewed the frequency and thematic focus of publications. As a result, we have provided practical guidance on how to use social networks in brand communications.
\end{abstract}

Keywords: public relations; corporate communications; brand communications; social networks; Facebook; Twitter; Instagram.

Introduction. In the modern information society, social networks play the key role in the development of corporate communications and public relations in general. This innovative type of media, based on online technologies, guided by the principles of self-organization, free distribution and commentary on messages, essentially opened a new era of transparent interactive relationships between companies and their target audiences. The speed, volume and intensity of information exchange (both textual and audio-visual) increased, content requirements changed, the new paradigm of communication in the network arose, which could not but affect the cultural, moral, psychological and other aspects of brands communicative behavior. Recent statistics show tendencies in increasing importance of online communications in the world. According to the researches, the number of Internet users in 2018 will reach 4,021 billion, which is $7 \%$ more than last year, and the number of social network users will reach 3,196 billion, which is $13 \%$ more than in 2017 [1]. Thus, it is possible to predict the further growth of business interest in digital technologies as an effective platform for communicating with its stakeholders.

Active research in the outlined scientific and applied branches unfolded in the 2000s. Among others, Greg Hearn, Marcus Foth and Heather Gray reviewed the features of the new media usage in corporate communications [2]. The attention of the scientists is drawn to the communication experience of the most successful companies and the methods of distributing their corporate content through social networks. For example, Svetlana Rybalko and Trent Seltzer investigated the communication activity of Twitter companies that are the part of the Fortune ranking - the list of 500 US corporations with the largest aggregate revenue for the relevant fiscal year [3]. Tina McCorkindale conducted content analysis of Facebook posts published by the top 50 Fortune-based companies [4]. In addition to applied approaches to using the most popular social networks, as well as blogs and forums, some scholars study the topics of publications to illustrate how companies manage their communication programs in the latest online space [5].

The study of Investis agency confirmed the dependence of financial and economic success of the largest companies in the United States and Great Britain on the use of their new media as the tool for corporate communications. In particular, the report states that companies rated FTSE 100 (the leading index of the British Stock Exchange) which link their corporate websites to social media and showed an increase from 35 to $72 \%$ in three years [6].

As this research has shown, Ukrainian companies are also actively using new media in corporate communications, but this phenomenon has not been reflected in scientific publications yet. The comparative aspect is of a particular interest: what are the similarities and differences between the international and Ukrainian brands behavior in social networks. By filling this gap, this research proposes the system knowledge and methodology to use social networks as the PR-tool.

The purpose of the research is to find out the patterns and differences in the behavior of international and Ukrainian brands in the most popular social networks.

The task is to outline the theoretical basis of the research question; to determine and compare quantitative and qualitative indicators of the representation of leading brands in the most popular social networks; analyse the frequency and thematic focus of publications.

Research methods. The empirical base is the publication of the most successful international and Ukrainian brands in social networks Facebook, Twitter, Instagram in 2017. The main method of research was content analysis as a qualitative and quantitative method for studying the content of communications. The statistical analysis of the audience was used to determine the representation of brands in social networks,

Results and discussion. Before turning to experimental methods, one should outline the theoretical field of the formulated scientific problem and, first of all, determine the functional load of social networks in the context of corporate communications as well as its relevance to the urgent business tasks. One can agree with the opinion of American researcher Lon Safko that "the most obvious is the use of social media for marketing, sales, public relations and communications. Remember that social media is about communicating with your customers. Social media is a set of highly effective tools for customer service, business-to-business (B2B) and internal communications" [7, 8]. Not less important advantage of social media is the considerable resource of trust and potential in involving the broad masses in the dialogue and attaining their loyalty, which is an important task of public relations. Obviously, this was what Asha Kaul and 
Vidhi Chaudhri, who, in one of their works, thoroughly analysed the possibilities of using social media in the context of managing the reputation of the company [8].

Thus, due to mass and targeting capabilities, social networks can reach the widest target audience (both external and internal), enabling the use of this media kind in all corporate communications types. Consequently, the role of social networks is seen, on the one hand, as a means of direct interaction with consumers to achieve marketing goals, or, as they say, "the creation of a virtual client environment" [5, 245]. On the other hand, it is a PR-tool for building an attractive brand image, forming loyalty of the audience, providing prospects for its sustainable development.

Other researchers point to a certain integrative social media function that helps companies to unite all corporate communication channels and enhance their impact. According to the scholars, the integration of social media has a powerful multiplying effect, especially when corporate Internet resources are interlinked: "when your content is syndicated outside, it gives you a double benefit: increasing your achievements and reducing your efforts. Integrating social media with existing business practices has the benefits of enhancing your real interaction with the target audience" [9, 18].

For our study, we took 10 most expensive international brands according to the American magazine Forbes: Apple, Google, Microsoft, Facebook, Coca-Cola, Amazon, Disney, Toyota, McDonald's, Samsung [10]. Ten of the leading Ukrainian trademarks were formed on the basis of the list of the "UkrBrand 2017: Ukrainian brands TOP 100: Morshynska, Sandora, Roshen, Nemiroff, Nova Poshta, Privatbank, Khortytsa, Rozetka, Kyivstar, Obolon" [11].
The preliminary defining of the most popular social networks in the world took place on the basis of the portal Statista data [12]. In the first step, the elements that are not system-formative for our study were excluded from the general ranking, namely, YouTube video hosting portal, the category of messengers, as well as nonglobalized social networks (e.g. Chinese QZone). As a result, there was created a revised list of social networks where Facebook has the first place in the world with the number of active users (almost 2.2 billion), followed by Instagram (1 billion) and Twitter (336 million) on the third.

To assess Ukrainian audience of social networks, there was used the research of Gemius company [13]. According to it, our fellow citizens also visit Facebook more often: just over half of all users $\log$ in to this social network from personal computers at least once a month ( $52 \%$ of the whole audience, 10.1 million users). Less Ukrainians use VKontakte (34\%, 6.7 million users), Instagram (13\%, 2.5 million), Twitter (8\%, 1.6 million). Taking into account that on May 15, 2017, by the decree of the President of Ukraine, the decision of the National Security and Defense Council "On the Application of Personal Special Economic and Other Restrictive Measures (Sanctions)" banned Russian website "VKontakte" in Ukraine. Now, the landscape of social networks in Ukraine consists of three main objects: Facebook, Twitter, and Instagram, which were taken as the basis for this study.

Analyzing the general characteristics of brands' representation in social networks, the attention should be drawn to the quantitative indicators of the audience.

\begin{tabular}{|c|c|c|c|c|c|c|}
\hline & \multicolumn{2}{|c|}{ Facebook } & \multicolumn{2}{c|}{ Twitter } & \multicolumn{2}{c|}{ Instagram } \\
\hline Company & $\begin{array}{c}\text { Audience } \\
\text { (amount of } \\
\text { followers), mln }\end{array}$ & $\begin{array}{c}\text { Publications } \\
\text { Quantity, } \\
2017\end{array}$ & $\begin{array}{c}\text { Audience } \\
\text { (amount of } \\
\text { followers), mln }\end{array}$ & $\begin{array}{c}\text { Publications } \\
\text { Quantity, } \\
2017\end{array}$ & $\begin{array}{c}\text { Audience } \\
\text { (amount of } \\
\text { followers), mln }\end{array}$ & $\begin{array}{c}\text { Publications } \\
\text { Quantity, } \\
2017\end{array}$ \\
\hline Apple & 11 & 0 & 1,8 & 0 & 6,2 & 90 \\
\hline Google & 26 & 184 & 20,6 & 981 & 6,5 & 266 \\
\hline Microsoft & 13 & 347 & 8,6 & 274 & 1,7 & 96 \\
\hline Facebook & 209 & 27 & 14 & 5 & 3 & 1 \\
\hline Coca-Cola & 107 & 44 & 3,4 & 100 & 2,5 & 38 \\
\hline Amazon & 28 & 582 & 2,8 & 896 & 1,3 & 281 \\
\hline Disney & 51 & 467 & 5,9 & 803 & 11,4 & 1019 \\
\hline Toyota & 3,8 & 587 & 0,726 & 612 & 1,1 & 243 \\
\hline McDonald's & 77 & 200 & 3,5 & 261 & 3,2 & 70 \\
\hline Samsung & 158,8 & 154 & 0,371 & 250 & 0,613 & 110 \\
\hline & $\mathbf{6 8 4 , 6}$ & $\mathbf{2 5 9 2}$ & $\mathbf{6 1 , 6 9 7}$ & $\mathbf{4 1 8 2}$ & $\mathbf{3 7 , 5 1 3}$ & $\mathbf{2 2 1 4}$ \\
\hline
\end{tabular}

Table 1. The US audience and publications quantity in social networks (international brands).

As the table below shows, the total audience of ten of the largest international brands in three social networks (Facebook, Twitter, Instagram) reaches almost 784 million people. This is more than $10 \%$ of the world's total population, which is 2.4 times bigger than the population of the United States, the third largest country in the world where 325 million people live. Although Ukrainian companies are currently actively developing domestic and foreign markets, they have considerably more modest indicators of reaching the general audience in social networks - 1 million 832 thousand people.

The largest aggregate audience of international brands was formed primarily by Facebook, with a total number of 684.6 million subscribers. It is 10 times more than Twitter (61.7 million) and almost 20 times more than Instagram (37.5 million)

The leaders in the number of Facebook subscribers are Facebook itself (209 million people), Samsung (almost 159 million) and Coca-Cola (107 million). Twitter ranked first with Google (20.6 million), followed by Facebook (14 million) and Microsoft (8.6 million). Instagram has the largest number of followers of Disney (11.4 million), Google (6.5 million), and Apple (6.2 million). Judging by the data, it is the IT companies (Google, Facebook, Apple) that have the largest audience in social networks. This is due to the special area of their activities, maxi- 
mum proximity to the users interests and a large number of news subjects.

However, the number of followers is not always the result of active communication with the audience. Apple's official Facebook page, which has 11 million subscribers, did not have any new posts in 2017. However, this corporation has some more official pages in this social network that operate in specialized areas: iTunes (30 million), App Store (14 million), Apple Music (3.7 million) which are active in a certain sphere. A similar situation is observed on Twitter. The official page of Apple has 1.8 million subscribers and 0 tweets. The Instagram account for this brand appeared on August 7, 2017 and was signed by 6.2 million users, however, only 90 photos were published per year.

Another global brand with a low communication activity is actually Facebook. Its official page in the same network has the largest number of (209 million) followers and only 27 posts in 2017 . On Twitter, the company managed to create five publications, in Instagram - only one. To sum up, for most social networks users, it's important to feel connected to the brand, even if it does not actively communicate with them.

In addition to reaching the audience, the visible marker of communication activity of brands in social networks is the frequency of publications. This indicator depends on two main factors. Firstly, it correlates with the format of communication offered by one or another social network.
For example, Twitter uses news as the base and limites text messages volume, so the posts here appear more often than on Facebook or Instagram. The largest number of publications among other social networks appeared on Twitter (4182 tweets per year or an average of 11 per day). The second position behind this option is Facebook (2592 posts a year or 7 per day), the third one is Instagram (2214 posts a year or 6 per day).

Secondly, the frequency of publications is dictated by the communication needs of each particular company, due to the specifics of its business activities. Toyota brand is the most active on Facebook (587 posts a year or an average of 1.6 a day), followed up by Amazon (582 posts a year or 1.6 a day) and Disney (467 posts a year or 1.3 a day). On Twitter, the leaders are Google (981 tweet a year or 2.7 a day), Amazon (896 tweets a year or 2.45 a day), and Disney (803 tweets per year or 2.2 per day). Instagram ranked Disney as the leader, which in 2017 created 1019 publications or an average of 2.8 per day. This indicator is the highest among all international brands studied in all social networks. With a significant difference, Amazon takes the secnd place on Instagram (281 posts a year or 0.8 per day) followed up by Google (266 posts a year or 0.7 per day).

In general, TOP-10 international brands are on average publishing 1.1 daily tweets on Twitter, 0.7 posts on Facebook and 0.6 posts on Instagram.

\begin{tabular}{|c|c|c|c|c|c|c|}
\hline & \multicolumn{2}{|c|}{ Facebook } & \multicolumn{2}{c|}{ Twitter } & \multicolumn{2}{c|}{ Instagram } \\
\hline Company & $\begin{array}{c}\text { Audience (amount } \\
\text { of followers), } \\
\text { thousands }\end{array}$ & $\begin{array}{c}\text { Publications } \\
\text { Quantity, } \\
2017\end{array}$ & $\begin{array}{c}\text { Audience (amount } \\
\text { of followers), } \\
\text { thousands }\end{array}$ & $\begin{array}{c}\text { Publications } \\
\text { Quantity, } \\
2017\end{array}$ & $\begin{array}{c}\text { Audience (amount } \\
\text { of followers), } \\
\text { thousands }\end{array}$ & $\begin{array}{c}\text { Publications } \\
\text { Quantity, } \\
2017\end{array}$ \\
\hline Morshynska & 22,6 & 161 & - & - & 6,6 & 137 \\
\hline Sandora & 10,5 & 118 & - & - & 2,2 & 89 \\
\hline Roshen & 149,6 & 167 & - & - & 34,2 & 169 \\
\hline Nemiroff & 16,1 & 41 & - & - & 119 & 0 \\
\hline Nova poshta & 163,1 & 158 & 1,5 & 0 & 19,2 & 74 \\
\hline PrivatBank & 103,6 & 265 & 127,2 & 114 & 2,1 & 0 \\
\hline Xopтuця & 120,5 & 292 & 95 & 40 & 14,5 & 261 \\
\hline Rozetka & 470 & 616 & 10,5 & 1116 & 67,4 & 699 \\
\hline Kyivstar & 257,1 & 316 & 8,7 & 275 & 2,6 & 0 \\
\hline Obolon & 8,3 & 98 & - & - & - & - \\
\hline & $\mathbf{1 3 2 1 , 4}$ & $\mathbf{2 2 3 2}$ & $\mathbf{2 4 2 , 9}$ & $\mathbf{1 5 4 5}$ & $\mathbf{2 6 7 , 8}$ & $\mathbf{1 4 2 9}$ \\
\hline
\end{tabular}

Table 2. The audience and publications quantity in social networks (Ukrainian brands).

There are almost no differences between the structures of Ukrainian and international brands representation. Their largest audience is concentrated on Facebook (1 million 321 thousand subscribers), with a big gap, on Instagram $(268,000)$, and on Twitter $(243,000)$. The low popularity of Twitter in Ukraine is also confirmed by the fact that 5 of 10 studied Ukrainian brands have no accounts there.

The leader in the number of Facebook subscribers is Rozetka (470 thousand), Kyivstar (257 thousand), and Nova Poshta (163 thousand). On Instagram, Nemiroff $(119,000)$, Rozetka $(67,000)$ and Roshen $(34,000)$ have the largest number of followers. On Twitter, PrivatBank (127 thousand) is ranked first in the coverage of the audience, followed up by Khortytsya (95 thousand) and Rozetka (10.5 thousand).

The largest number of publications among other social networks Ukrainian brands made on Facebook (2232 posts a year or an average of 6 per day), on Twitter (1545 tweets per year or 4 per day), and on Instagram (1429 posts a year or almost 4 per day).

The most frequently published posts on Facebook are by Rozetka (616 posts a year or an average of 1.7 per day), Kyivstar (316 posts a year or 0.9 per day), and Khortytsa (292 posts a year or 0.8 per day). On Instagram, the leaders are Rozetka (699 publications or an average of 1.9 per day), Khortytsia (261 publications per year or 0.7 per day), and Roshen (169 publications per year or 0.5 per day). On Twitter the leader is Rozetka (1116 tweets a year or 3 per day). This indicator is the highest among Ukrainian brands in all social networks and even overtakes the activity of the international Disney corporation on Instagram, which has 1019 publications or an average of 2.8 per day. The second place in the frequency of posts on Twitter takes Kyivstar (275 tvits per year or 0.75 a day) followed up by PrivatBank (114 tvits per year or 0.3 per day). 
In general, TOP-10 Ukrainian brands on average publish 0.8 tweets on Twitter daily, 0.6 posts on Facebook and 0.4 posts on Instagram. Note that Ukrainian companies post on Facebook and Instagram with roughly the same frequency as Western corporations, but much less frequently on Twitter.

The second part of this research was the study of the publications thematic directions in social networks.

During content analysis, there were highlighted five major thematic vectors represented in the communications of most international and Ukrainian brands:
1) product information (posts containing product / service information of the company, presentation of the new product / service);

2) entertainment material (publications intended to activate an audience, attract its attention, whether or not related to the product or company);

3) educational material (publications that have useful or new cognitive information for the reader);

4) holiday greetings (publications that announce important dates);

5) stories (posts that tell about the success of people and the achievement of the companies, etc.).

\begin{tabular}{|c|c|c|c|c|c|c|c|c|c|c|c|c|c|c|c|}
\hline \multirow[b]{2}{*}{ 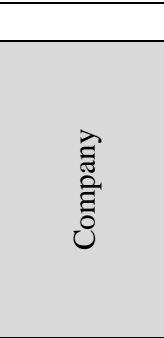 } & \multicolumn{6}{|c|}{ Facebook } & \multicolumn{5}{|c|}{ Twitter } & \multicolumn{4}{|c|}{ Instagram } \\
\hline & 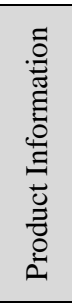 & 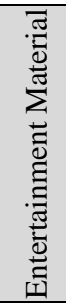 & 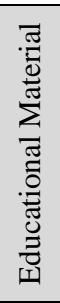 & 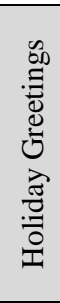 & $\frac{\mathscr{0}}{\overrightarrow{0}}$ & 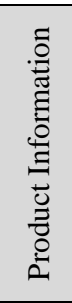 & 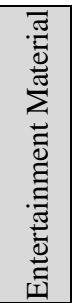 & 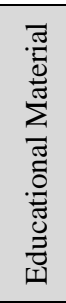 & 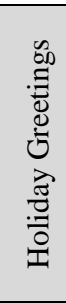 & $\begin{array}{l}\stackrel{0}{\tilde{D}} \\
\stackrel{0}{\infty}\end{array}$ & 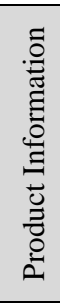 & 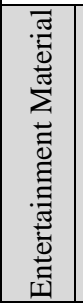 & 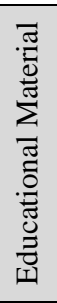 & 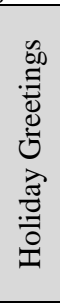 & $\frac{\tilde{0}}{\tilde{0}}$ \\
\hline Apple & 0 & 0 & 0 & 0 & 0 & 0 & 0 & 0 & 0 & 0 & 0 & 90 & 0 & 0 & 0 \\
\hline Google & 64 & 30 & 31 & 27 & 25 & 275 & 273 & 115 & 170 & 135 & 18 & 184 & 1 & 11 & 51 \\
\hline Microsoft & 87 & 9 & 41 & 2 & 189 & 56 & 15 & 30 & 2 & 116 & 11 & 13 & 0 & 0 & 67 \\
\hline Facebook & 11 & 3 & 0 & 5 & 10 & 1 & 0 & 1 & 2 & 0 & 1 & 0 & 0 & 0 & 0 \\
\hline Coca-Cola & 13 & 17 & 0 & 13 & 0 & 44 & 38 & 0 & 18 & 0 & 23 & 5 & 0 & 10 & 0 \\
\hline Amazon & 378 & 86 & 8 & 17 & 82 & 649 & 90 & 6 & 24 & 102 & 156 & 91 & 0 & 21 & 8 \\
\hline Disney & 145 & 243 & 31 & 17 & 19 & 207 & 459 & 45 & 56 & 27 & 167 & 806 & 3 & 33 & 9 \\
\hline Toyota & 297 & 201 & 9 & 10 & 40 & 254 & 208 & 9 & 10 & 84 & 131 & 110 & 0 & 2 & 0 \\
\hline McDonald's & 135 & 22 & 0 & 10 & 30 & 136 & 74 & 0 & 20 & 17 & 60 & 4 & 0 & 4 & 1 \\
\hline Samsung & 87 & 41 & 0 & 0 & 18 & 137 & 6 & 16 & 1 & 60 & 79 & 29 & 1 & 1 & 0 \\
\hline & 1217 & 652 & 120 & 101 & 413 & 1759 & 1163 & 222 & 303 & 541 & 646 & 1332 & 5 & 82 & 136 \\
\hline
\end{tabular}

Table 3. The Quantity of Different Thematic Direction Publications of International Brands in Social Networks.

The most widespread vector of international brands communications represented in social networks is "product information" (a total of 3,622 publications). The second position is taken by "entertainment material" (3147), the third is "stories" (1090), the fourth is "holiday greetings" (486) and the last one is "educational material" (347).
It should also be noted that the nature of the posts depends on the specifics of the social network. For example, the largest amount of materials on Facebook and Twitter (1217 and 1759, respectively) is product information that companies use to present their new products. Instagram has an entertaining content predominantly (1332 publications). At the same time, there are no posts of educational orientation and almost no "stories" format is used.

\begin{tabular}{|c|c|c|c|c|c|c|c|c|c|c|c|c|c|c|c|}
\hline \multirow[b]{2}{*}{ 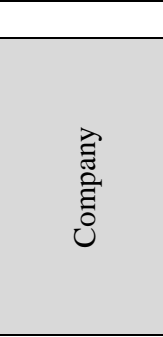 } & \multicolumn{5}{|c|}{ Facebook } & \multicolumn{5}{|c|}{ Twitter } & \multicolumn{5}{|c|}{ Instagram } \\
\hline & 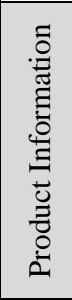 & 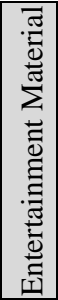 & 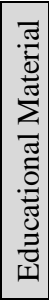 & 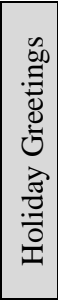 & $\frac{\tilde{s}}{\stackrel{0}{0}}$ & 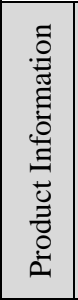 & 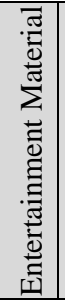 & 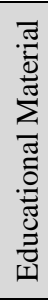 & 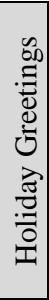 & 造 & 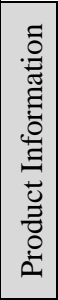 & 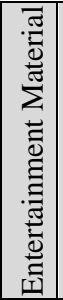 & 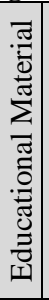 & 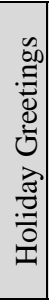 & 兽 \\
\hline Morshynska & 24 & 111 & 0 & 10 & 16 & - & - & - & - & - & 17 & 107 & 0 & 5 & 8 \\
\hline Sandora & 2 & 107 & 1 & 4 & 4 & - & - & - & - & - & 0 & 84 & 0 & 5 & 0 \\
\hline Roshen & 76 & 59 & 0 & 8 & 24 & - & - & - & - & - & 47 & 117 & 0 & 5 & 0 \\
\hline Nemiroff & 7 & 34 & 0 & 0 & 0 & - & - & - & - & - & 0 & 0 & 0 & 0 & 0 \\
\hline Nova poshta & 78 & 60 & 0 & 10 & 10 & 0 & 0 & 0 & 0 & 0 & 25 & 40 & 0 & 7 & 2 \\
\hline PrivatBank & 123 & 120 & 1 & 7 & 14 & 38 & 75 & 0 & 0 & 1 & 0 & 0 & 0 & 0 & 0 \\
\hline Хортиця & 233 & 45 & 9 & 2 & 3 & 11 & 27 & 0 & 2 & 0 & 242 & 16 & 0 & 3 & 0 \\
\hline Rozetka & 400 & 212 & 0 & 4 & 0 & 833 & 192 & 68 & 1 & 22 & 430 & 254 & 0 & 15 & 0 \\
\hline Kyivstar & 196 & 79 & 2 & 30 & 9 & 190 & 46 & 0 & 30 & 9 & 0 & 0 & 0 & 0 & 0 \\
\hline \multirow[t]{2}{*}{ Obolon } & 14 & 46 & 10 & 25 & 3 & - & - & - & - & - & - & - & - & - & - \\
\hline & 1153 & 873 & 23 & 100 & 83 & 1072 & 340 & 68 & 33 & 32 & 761 & 618 & 0 & 40 & 10 \\
\hline
\end{tabular}

Table 4. The Quantity of Different Thematic Direction Publications of Ukrainian Brands in Social Networks.. 
Amazon places product information more often than others, on both Facebook and Twitter (correspondingly, 378 and 649 publications). This is due to the specifics of the business of this company, which provides an online service for the sale of mass demand goods. Disney Corporation, which is the world leader in the entertainment industry and delivers its content to all social networks accounts in the appropriate entertainment manner, has the similar situation. In addition, the peculiarities of the Disney brand makes Instagram a perfect platform for publishing visual content. Educational materials are most often published by Google and Microsoft, which work in the innovative digital area and whose activities require clarification. Also, these two brands hold leadership in using the "stories" format.

In Ukrainian segment, as well as in the international, the most widespread vector for all studied social networks is "product information" (a total of 2986 publications) followed up by "entertainment material" (1831), "holiday greetings" (1090), "stories" (125), and "educational material" (91).

The largest number of Ukrainian brands publications is dedicated to their own products and posted on Facebook and Twitter (correspondingly, 1153 and 1072 publications). The second most popular place is the entertainment material prevailing on Facebook and Instagram (873 and 618 publications, respectively).

Rozetka places the information about the product both on Facebook and Twitter more often (respectively, 400 and 833). Like Amazon, Ukrainian Rozetka deals with online sales of a wide range of products, so the vast majority of its publications are intended to inform the audience about the large number of new products. At the same time, Rozetka is an absolute leader in publishing entertainment materials in all social networks. As the content analysis has shown, Ukrainian brands rarely use the thematic format of educational materials, although it could be useful for leaders of the banking and telecommunication sectors to promote their innovative services.

Conclusions. The research has confirmed that the most successful international and Ukrainian brands actively use social networks in their PR communications to spread information about their new products or services, as well as to form and maintain loyal audiences through entertainment publications. The main indicators of the brands representation in social networks is the audience coverage (number of subscribers) and the frequency of publications.

In general, for the most effective communication between the brands and the audience, it is enough to use three main social networks with the highest reach: Facebook, Twitter, Instagram. The choice of this or that social network is dictated by the specifics of the business, as well as the content format of the social network itself.

As the analysis showed, despite the active use of individual brands of the microblogging platform Twitter, Facebook could claim the title of the most demanded social network in corporate communications. At the same time, Instagram has the smallest general audience and the number of publications studied in the world. This suggests that brand target audiences still favor textual and combined textual-visual content rather than visual. News content remains the most popular and relevant in social networks.

Based on the experience of international and Ukrainian brands, depending on specific PR-goals, the optimal frequency of publications in social networks can be considered: one to two tweets per day on Twitter and one to two posts in two days on Facebook and Instagram.

In addition to product and entertainment information, brands should use the potential of motivational stories and educational publications in social networks more actively to gain greater awareness and loyalty of the audience, which is an important factor in business development.

\section{REFERENCES}

1. Kemp, S. (2018), "Digital in 2018: World's Internet Users Pass the 4 Billion Mark", available at: https://wearesocial.com/blog/2018/01/global-digital-report2018 (accessed 09 September 2018).

2. Hearn, G., Foth, M., \& Gray, H. (2008), "Applications and Implementations of New Media in Corporate Communications. An Action Research Approach", Corporate Communications: An International Journal, Vol. 14, No. 1, pp. 49-61.

3. Rybalko, S. \& Seltzer, T. (2010), "Dialogic Communication in 140 Characters or Less: How Fortune 500 Companies Engage Stakeholders Using Twitter", Public Relations Review, Vol. 36, No. 4, pp. 336-341.

4. McCorkindale, T. (2010), "Can You See the Writing on My Wall? A Content Analysis of the Fortune 50's Facebook Social Networking Sites", Public Relations Journal, Vol. 4, No. 3, pp. 1-13.

5. Culnan, M., McHugh, P.J. \& Zubillaga, J.I. (2010), "How Large U.S. Companies Can Use Twitter and Other Social Media to Gain Business Value", MIS Quarterly Executive, Vol. 9, No. 4, pp. 243-259.

6. Colwyn, S. (2015), "How is Social Media Used for Corporate Communications?", available https://www.smartinsights.com/social-mediamarketing/social-media-governance/ukusasocial-mediaresearch-for-corporates/ (accessed 20 September 2018).

7. Safko, L. (2010), The Social Media Bible: Tactics, Tools, and Strategies for Business Success, 2-nd ed., John Wiley \& Sons, Hoboken, New Jersey, 771 p.
8. Kaul, A. \& Chaudhri, V. (2017), Corporate Communication through Social Media: Strategies for Managing Reputation, SAGE Publications Pvt. Ltd, 252 p.

9. Sweeney, S. \& Craig, R. (2010), Social Media for Business: 101 Ways to Grow Your Business Without Wasting Your Time, Maximum Press, $217 \mathrm{p}$.

10. Forbes (2017), "Forbes Releases Seventh Annual World's Most Valuable Brands List", available at: https://www.forbes.com/sites/forbespr/2017/05/23/forbesreleases-seventh-annual-worlds-most-valuable-brandslist/\#482154af5b55 (accessed 21 September 2018).

11. MPP Consulting (2017), "UkrBrand 2017", available at: http://www.mppconsulting.com.ua/ukrbrand/ukrbrand2017.p df (accessed 09 September 2018).

12. Statista (2017), "Most Famous Social Network Sites Worldwide as of July 2018, Ranked by Number of Active Users (in millions)", available https://www.statista.com/statistics/272014/global-socialnetworks-ranked-by-number-of-users/ (accessed 20 September 2018).

13. Gemius (2017), "Social Networks: Who Uses and How?", available at: http://www.gemius.com.ua/e-commercenovosti/socialni-merezhi-xto-vikoristovuje-i-jak.html (accessed 21 September 2018). 